\title{
Obituary: SOME MEMORIES OF PAT MORAN
}

In May 1953, I was sent for the remainder of that year to the Australian National University (ANU) in Canberra by Australia's central bank, where I was then a junior research officer. Feeling rather lost and lonely, I was reading in the library when Pat Moran looked over my shoulder and, noticing what I was reading, asked me to come and see him. This event altered my life, for I then came into close contact with a man of firstclass mind and of generous scientific spirit.

Patrick Alfred Pierce Moran was born in Sydney on 14 July 1917, his father, H. A. Moran, being a distinguished surgeon and an athlete. Indeed he was the captain of the first Australian rugby team to tour the UK. H. A. Moran was a man of broad interests who also wrote two autobiographical books, Over the Hill Lies China and Viewless Winds. Both are of value, particularly in relation to the history of Sydney at that time.

Pat Moran was an only child. His mother was apparently Rhesus negative and all her subsequent babies died soon after birth. This perhaps explains why Pat's childhood may not have been fully happy. One incident permanently marked him. While being operated on for appendicitis, Pat vomited and choked. In performing a tracheotomy to save the child's life, the surgeon accidentally cut Pat's vocal chords. As a result Pat spoke in a lowregister husky voice that intrigued people when they first heard it, but to which they soon became accustomed.

Pat's education was interrupted by this and other illnesses. He was clearly gifted. His father wished him to study medicine but Pat took a science degree, majoring in mathematics at the University of Sydney, and was awarded first-class honours. He then went to the University of Cambridge and later commenced postgraduate study under the supervision of the distinguished Russian mathematician Besicovich, for whom Pat developed warm affection as well as admiration.

Pat told many stories about his Cambridge days, one of which concerns Enoch Powell. He was then about to go to Sydney as professor of classics, and Pat, having heard that Powell was interested in Sydney examination standards, went to his room with a set of papers. He knocked at the door, entered, and told Powell what he had brought. 'Put the papers on the table by the door as you leave' were the only words he ever heard from that famous man.

Pat Moran was a man singularly free of vanity. He was by no means humble, however, and once himself told me that he thought himself arrogant; this was an exaggeration. He often told tales against himself, for example that in his first paper he proved properties of a non-existent set, and that a tutor at Cambridge told him he would never make a living at mathematics. If I have guessed this tutor's identity correctly, his scientific achievements were rather minor. 


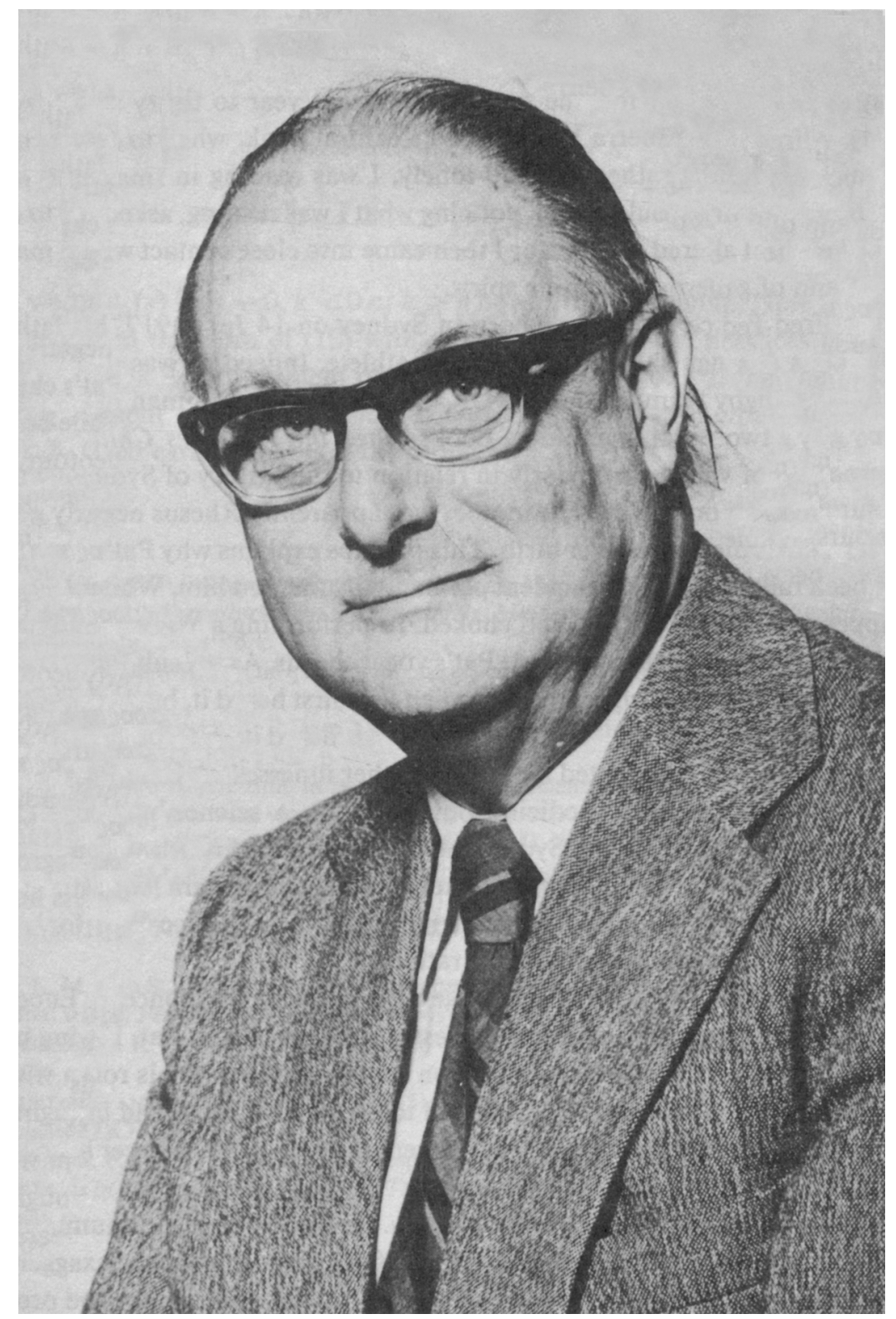

P. A. P. MORAN, 1917-1988 
During the Second World War, Pat was involved in scientific work in London. He met and married his wife, Jean, with whom he lived in happiness for the rest of his days. They had three children, Louise, Michael and Hugh, and several grandchildren. A strong and courageous woman, Jean staunchly supported him in the difficult time towards the end of his life.

Pat Moran had only recently arrived at ANU in 1952 when I first met him. He had come from Oxford to be the first professor of statistics in the Research School of Social Sciences (RSSS). If I remember correctly, Pat became interested in statistics after helping his friend Maurice Kendall to correct the proofs of The Advanced Theory of Statistics. At Oxford he was associated with the economist Richard Stone, later a Nobel laureate. RSSS may have thought that Pat was a high-quality mathematical statistician with an interest in the social sciences; they were mistaken about the last. Indeed, Pat often disparaged economics, though in part this may have been because he enjoyed provoking me into earnest expostulation. Given a free hand, he made his Department of Statistics essentially one of mathematical research into probability and statistics. This was not quite what the RSSS had envisaged, but although slightly critical, his colleagues were tolerant of this mathematically oriented research.

The chair of statistics at ANU was special in that there were no undergraduate responsibilities. Ph.D. students were examined only by a thesis, and the number of students was small; the task was consequently one of research and the supervision of rather good students. J. M. Gani arrived soon after I did and the three of us developed a strong friendship, though both Joe Gani and I had occasional disagreements with Pat.

It had been customary for high-quality Australian graduates to leave Australia, often for England, where they pursued the further study of their subject. Some, of course, went to the USA, G. S. Watson (who joined Moran's department in its early days) being an example. The fact that there were so many talented Australian graduates gave Moran a great opportunity, which he seized, for these graduates now became aware that there was a fine scholar anxious to train good students in Australia. A stream of first-class Ph.D. students thus came to Canberra, many of whom Pat Moran supervised personally. He also attracted high-quality staff and many visitors from overseas.

Moran himself produced a stream of papers and books on pure and applied probability, especially geometric probability and the theory of storage systems, on statistical theory, on population genetics and on statistical problems in social psychiatry. (See the list of his 171 publications up to 1981 in J. Appl. Prob. 19A (1982).) He was elected a Fellow of the Australian Academy of Science in 1962 and of the Royal Society in 1975.

My memories of him are multitudinous: his husky voice, the signal that he had arrived in the morning from his knocking the ash out of his pipe, his generosity and conviviality as a host, his deeply held religious beliefs accompanied by sharp criticism of some Catholic attitudes. He manifested an intense dislike of politics, especially when the conservative side he supported was faring badly. He was interested in literature less in the forms of the novel, poetry, drama than in biography, especially scientific biography which he read with profound pleasure. He had an excellent sense of humour and could be acid at times. He was interested in music. He had no interest in sport. He took little exercise. 
Pat retired at the end of 1982 when he was 65 years old. He was then offered an office in the Social Psychiatry Research Unit at ANU, headed by his friend Scott Henderson, and worked there until mid 1987 when he suffered a stroke.

Pat's stroke incapacitated him, for he was paralysed in the left arm and leg, but it did not destroy his spirit. I recall his asking me to pray for him; when I said that I doubted if this would have much influence, he replied 'Well, it may give them a shock to hear from you.' He was most anxious to attend Joe Gani's invited address at the bicentennial meeting of the Australian Mathematical Society in May 1988, and we wheeled him into the large auditorium where very many of his friends from Australia and overseas greeted him. A few months later he died of a heart attack, on 19 September 1988.

Tumultuous personal feelings fill one's mind at such a time, on which it is perhaps wisest to remain silent. He was an unusual man of great gifts, and those who knew him well could not fail to be captivated by his personality; we all feel a great sense of loss at his passing.

Australian National University

E. J. HANNAN

Canberra, Australia

October 1988 